\title{
The Global Trade Slowdown: Cyclical or Structural?
}

\section{Cristina Constantinescu, Aaditya Mattoo, and Michele Ruta}

\begin{abstract}
This paper focuses on the sluggish growth of world trade relative to income growth in recent years. We use a simple empirical strategy based on an error correction model to assess whether the global trade slowdown is structural or cyclical. An estimate of the relationship between trade and income in the past four decades reveals that the long-term trade elasticity rose sharply in the 1990s, but declined significantly in the 2000s, even before the global financial crisis. These results suggest that trade is growing slowly not only because of slow GDP growth, but also because of a structural change in the trade-GDP relationship in recent years. The available evidence suggests that a key driver of structural change over the 2000s is the slowing pace of international vertical specialization, which accounts for between one-quarter and one-half of the decline in import growth from the 1990 s to the 2000 s.
\end{abstract}

JEL classification: F14, F40

Keywords: Global Trade Slowdown, Trade Elasticity, Global Value Chains

\section{Introduction}

After bouncing back from the historic low of the Great Recession in 2010, world trade has grown on average by 3.0 percent since 2012, compared to the pre-crisis average of 7.1 percent (1987-2007). This slowdown has received much attention and has been the subject of debate since it first appeared. ${ }^{1}$ One important question is whether the slower growth in trade simply reflects the sluggishness of GDP or whether there is a structural shift in the relationship between trade and GDP. Furthermore, if there is indeed a structural shift, is it a post-crisis phenomenon or does it reflect longer-term developments?

Cristina Constantinescu is an economist in the Macroeconomics, Trade \& Investment Global Practice at the World Bank; her email address is ineagu@worldbank.org. Aaditya Mattoo (corresponding author) is research manager of the Trade \& International Integration Team of the World Bank’s Development Research Group; his email address is amattoo@worldbank.org. Michele Ruta is lead economist in the Macroeconomics, Trade \& Investment Global Practice at the World Bank; his email address is mruta@worldbank.org. Research for this paper has been supported by the World Bank's Multi-Donor Trust Fund for Trade and Development and the Strategic Research Program. The authors are grateful for comments from seminar participants at the IMF, the World Bank, the 2014 Villa Mondragone International Economic Seminar, and the Third IMF/WB/WTO Trade Workshop, and to Tam Bayoumi, Chad Bown, Ruo Chen, Allen Dennis, Romain Duval, Hubert Escaith, Simon Evenett, Caroline Freund, Martin Kaufman, Ayhan Kose, Pascal Lamy, Alen Mulabdic, Franziska Ohnsorge, Alberto Osnago, Nina Pavcnik (the Editor), Mika Saito, Mohammed Saleh, Silvia Sgherri, Hans Timmer, and two anonymous referees for many useful suggestions. A supplementary online appendix for this article can be found at The World Bank Economic Review website.

1 Early discussions include, for example, Davies (2013) and Krugman (2013). 
We use a simple empirical strategy based on an error correction model to address these questions. We first estimate the relationship between trade and income for the period 1970-2015, using yearly data. While the global trade slowdown is a recent phenomenon, the analysis of a long time period can shed light on structural changes that may have occurred in the trade-income relationship, and that may help explain more recent events. We find that the recent trade slowdown can be traced to trade in goods rather than services. The long-term elasticity of trade in goods with respect to income was 1.1 between 1970 and 1985, rose to 2.2 in the period 1986-2000, and then declined to 1.6 in the 2000s. Statistical tests confirm that the estimate for the 1990s is significantly different from the estimates for the 1980s and the 2000s.

A focus on the 2000s shows that the decline in the long-run trade elasticity, from the high levels of the 1990s, set in before the global financial crisis and was accentuated in the post-crisis world. Using quarterly data, we divide the entire period into three parts: the 1990s, 2000-2007 (pre-crisis period), and 2008-2015 (post-crisis period), and estimate the long-run trade elasticity in each of the three periods. We find that a 1 percent increase in income was associated with a 2.9, 2.5, and 1.0 percent increase in trade in goods in the periods 1991-2000, 2001-2007, and 2008-2015, respectively. The differences in the three elasticities are statistically significant and robust to a number of tests.

Next, we use the results of our empirical model to decompose the cyclical and structural components of trade growth. We find that while cyclical effects dominate during periods of crisis such as the trade collapse of 2008 and 2009, the current global trade slowdown is in significant part explained by a decline in the structural component of trade growth. This decline, in turn, mostly results from the lower elasticity of trade to GDP in the 2000s relative to the 1990s.

We find that a key driver of structural change over the 2000s is the slowing pace of international vertical specialization, which accounts for between one-quarter and one-half of the decline in import growth from the 1990s to the 2000s. The long-run trade elasticity increased during the 1990s as production fragmented internationally into global supply chains and decreased in the 2000s as this process decelerated. For example, as we show below, Chinese exporters are now using more domestically produced inputs than imported inputs; the share of Chinese imports of parts and components in total exports has decreased from 55 percent in the mid-1990s to 35 percent today. Other factors may have contributed to the lower responsiveness of trade to income, particularly the declining share of investment in GDP after the financial crisis, but the evidence suggests that their role was less important.

Why might the changing trade-income relationship matter? Some, such as Paul Krugman, have argued that it does not, and that "the flattening out is neither good nor bad, it's just what happens when a particular trend reaches its limits” (Krugman 2014). Others take the opposite view. For instance, in a speech as governor of the Central Bank of India, Raghuram Rajan concluded that "We are more dependent on the global economy than we think. That it is growing more slowly, and is more inward looking, than in the past means that we have to look to regional and domestic demand for our growth" (Rajan 2014). On the one hand, if openness per se is associated with dynamic benefits, trade will continue to foster growth since most economies are more open today in terms of the share of trade in GDP than they were in the 1990s. On the other hand, if the expansion of trade growth relative to GDP growth, as in the 1990s, contributes to countries' economic growth, the flattening of this trend will imply a smaller contribution of trade to growth. Constantinescu, Mattoo, and Ruta (2016) suggest that the changing trade-income relationship may raise two types of concerns. One is a demand-side "Keynesian" concern, that sluggish world import growth may adversely affect individual countries' economic growth by limiting opportunities for their exports. The other is a supply-side "Adam Smithian" concern, that slower trade may diminish the scope for productivity growth through increasing specialization and diffusion of technologies. They find some evidence for the second channel.

Our work relates to three strands in the economic literature. A first set of papers analyzed the changes in the long-run relationship between trade and income. Irwin (2002) documents the variation of the world 
trade elasticity between 1870 and 2000, providing valuable insights into the underlying factors. Freund (2009) calculates the elasticity of trade to GDP in tranquil and crisis times, and shows that the latter tends to be higher. Escaith, Lindenberg, and Miroudot (2010) provide evidence of the increase in the world trade elasticity in the 1990s and relate this to the process of vertical specialization. As distinct from these studies, our main interest is in understanding the extent to which changes in the long-run trade and income relationship can explain the global trade slowdown. We also attempt to analyze in a more systematic way some of the factors that may underpin the changing relationship between trade and GDP.

Our work also relates to the wide literature on the trade collapse of 2008-2009 (among others, Bems, Johnson, and Yi 2010; Levchenko, Lewis, and Tesar 2010; Bussiere et al. 2013; Abiad, Mishra, and Topalova 2014). ${ }^{2}$ This literature studies the causes of the sudden, severe, and synchronized collapse of world trade that followed the global financial crisis in 2008-2009. The emerging consensus is that the driving factor of the collapse was the sharp contraction in aggregate demand, concentrated on trade-intensive components, and amplified by other factors, such as inventory effects and trade credit constraints (Bems, Johnson, and Yi 2013). Our study complements this work by taking a longer-term view and investigating the structural versus cyclical determinants of the current trade slowdown. Interestingly, we document that while cyclical factors dominated the trade collapse, structural determinants are more relevant to understanding the current slowdown.

Finally, there is a recent literature-subsequent to the first version of this paper-that also focuses on the trade slowdown and its determinants. One set of papers confirms a structural change in the tradeincome relationship around the beginning of the century (e.g., ECB 2016), whereas others focus on the change after the financial crisis (Timmer et al. 2016). As regards the determinants of the slowdown, the research confirms the importance of changing vertical specialization (e.g., Haugh et al. 2016; IMF 2016; ECB 2016; Timmer et al. 2016). ${ }^{3}$ However, some have also emphasized the (relative) importance of cyclical factors and changes in the composition of aggregate demand, away from relative import-intensive investment toward consumption (Boz, Bussiere, and Marsilli 2015; Ollivaud and Schwellnus 2015; IMF 2016; Freund 2016). As discussed below, while this latter explanation may be valid for the post-crisis period, it is less plausible for what happened before the crisis because for much of the early 2000s, the share of investment in aggregate demand was increasing.

The rest of the paper is organized as follows. In section 2, we present some stylized facts about the trade slowdown and estimate the elasticity of trade with respect to GDP for the period 1970-2015, taking also a closer look at the 2000s, pre- and post-Great Recession. In section 3, we decompose the trade slowdown into its cyclical and structural components. Section 4 presents an analysis of the factors that may explain the decline in long-term elasticity. Section 5 concludes.

\section{An Analysis of the Trade-Income Relationship}

Trade recovered after the global financial crisis, but trade growth has been sluggish since then. After a solid post-recession rebound in 2010, when the volume of global trade rose 12 percent, trade volumes grew by 7.1 percent in 2011 and, on average, 3 percent thereafter. This recent growth rate is well below the pre-crisis average trade growth of 7.1 percent (1987-2007) and is slightly below the growth rate of world GDP in real terms, which has hovered around 3 percent in recent years. These recent developments in international trade growth are now commonly referred to as the "global trade slowdown" (see, for instance, Donnan [2014]).

Proximate explanations of the global trade slowdown link it to changes in world GDP and, hence, to cyclical factors, including ones related to the fallout of the global financial crisis. However, a somewhat

Early contributions to this literature were collected in Baldwin (2009).

Escaith, Lindenberg, and Miroudot (2010) had earlier conjectured that changes in vertical specialization were playing a role in changing elasticities, but their approach yielded no supporting evidence. 
Figure 1. Ratio of 10 -Year Average Trade Volume Growth to 10-Year Average Real GDP Growth

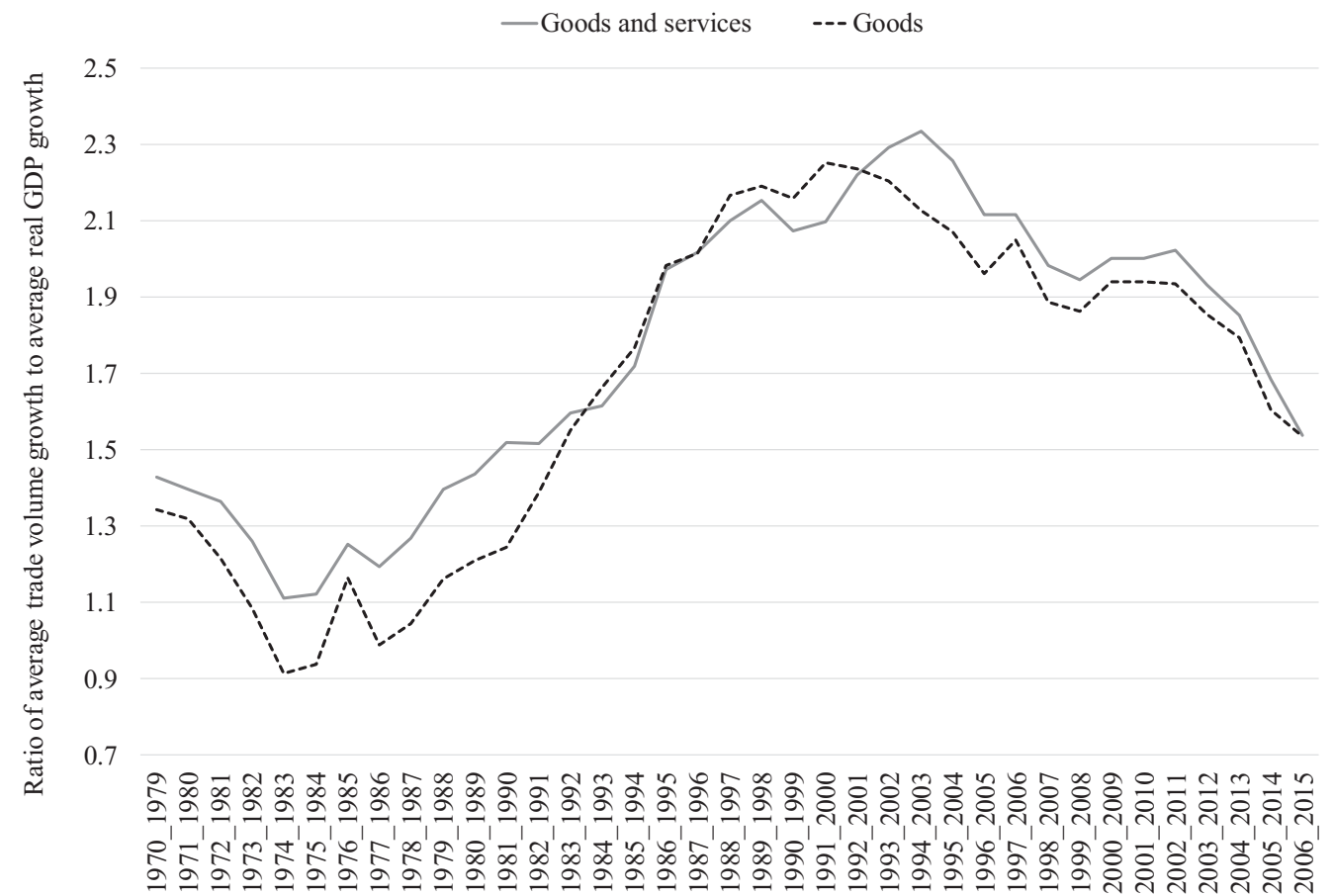

Source: Authors' calculations based on World Bank's World Development Indicators (WB WDI) and World Trade Organization's World Trade Statistics Review (WTO WTSR).

Note: Indicators used in calculation: from WB WDI-Imports of goods and services in constant 2010 US\$ and GDP at market prices in constant 2010 US\$ (for indicator codes, see table S1.1 in the supplementary online appendix); from WTO WTSR: world export volume of merchandise, $2005=100$; world GDP, real (market exchange rates), $2005=100$. Years 2000, 2001, and 2009 are excluded from the calculation of the averages.

different view emerges when we look at the dynamic of the income elasticity of trade-measured as the ratio of trade volume growth to real GDP growth computed on rolling 10-year windows (fig. 1). The elasticities are lowest around the 10-year period 1977-1986, highest around the 10-year period 19901999, and decline after that. ${ }^{4}$ This pattern suggests a structural change in the relationship between trade and income that set in well before the crisis. Specifically, the period 1986-2000, which we call the "long 1990s," would seem to be different from the preceding and the subsequent period. ${ }^{5}$ In the ensuing analysis, we rigorously examine the presumption of two breaks in the trade-income relationship, one dip in the early 2000s and another sharper one after the crisis.

To examine the relationship between trade and income in greater detail, we follow the literature and use the Error Correction Model (ECM) representation of the first-order autoregressive distributed-lag model or ARDL $(1,1)$. This specification is generally sufficient to ensure a white noise error term. ${ }^{6}$ In particular, we are interested in estimating the long-run income elasticity of trade (in short, the trade elasticity), which measures the long-run relationship between trade and income. We also estimate the short-term determinants of trade: the short-run trade elasticity, which measures the relationship between

$4 \quad$ Figure S1.1 in the supplementary online appendix also shows that while after the crisis most countries/regions have a stable import-to-GDP ratio, this relative "flatness" appears to predate the crisis for China and the United States, where import volumes as a share in real GDP have barely increased for nearly a decade.

5 This terminology borrows from Eric Hobsbawm's characterization of the "long 19th century" as the period between the years 1789 and 1914 .

6 See Irwin (2002); Escaith, Lindenberg, and Miroudot (2010). 
trade and income in the short run, and the speed of adjustment to the long-run equilibrium. Specifically, we run a regression of the form

$$
\Delta \ln m_{t}=\alpha+\beta * \Delta \ln y_{t}+\gamma * \ln m_{t-1}+\delta * \ln y_{t-1}+\varepsilon_{t},
$$

where $\Delta$ denotes first differences, $\mathrm{m}_{\mathrm{t}}$ is the import volume, and $\mathrm{y}_{\mathrm{t}}$ is real GDP at time $\mathrm{t}, \alpha$ is a constant, and $\varepsilon_{\mathrm{t}}$ is the error term. ${ }^{7}$ In this framework, the short-run trade elasticity is $\beta$, while the speed of adjustment to the long-run equilibrium is $-\gamma$. The long-run trade elasticity is given by $-\delta / \gamma{ }^{8}$

\section{Trade and Income in 1970-2015: Annual Data}

In this subsection, we begin to look at the trade-income relationship using annual data for the period 1970-2015. While the global trade slowdown is a recent phenomenon, investigating a sufficiently long time period is essential to detect structural changes that may have occurred in the relationship between trade and income. The results for this period are presented in table 1 and are confirmed by robustness checks (including the use of alternative data sources, vintages, or measures of world real GDP) provided in table S1.2 of the supplementary online appendix. ${ }^{9,10}$ Regressions are run for various categories of trade, to examine whether changes in total trade elasticity reflect shifts in composition toward trade categories with lower income elasticity of demand. ${ }^{11}$ Within each regression, parameters are allowed to vary across three subsamples: 1970-1985, 1986-2000, and 2001-2015. ${ }^{12}$ The next subsection will take a closer look at the dynamics of the trade in goods and income data before and after the Great Recession.

The relationship between trade and income differs considerably across the three periods. In the period 1986-2000, a 1 percent increase in world real GDP was associated with a 2.1 percent increase in the volume of world trade. This elasticity was substantially higher than in the preceding period (1970-1985) and in the subsequent period (2000-2015), for which the trade elasticities were 1.3 and 1.5, respectively. The main force in the decline of the world trade elasticity was the fall of the goods trade elasticity in the 2000s, which in turn was driven by manufacturing trade. At the world level, the long-run trade in goods

7 Phillips-Perron unit root tests indicate that both import volume and real GDP are I(1).

8 As discussed in the introduction, these types of import demand equations have been widely used in the empirical trade literature (including, more recently, in Irwin [2002]; Freund [2009]; Escaith, Lindenberg, and Miroudot [2010]; and Bussiere et al. [2013]).

9 World real GDP growth is a weighted average of country-specific real GDP growth rates. The weights used by international organizations to compute real GDP growth at the world level include: GDP in international PPP dollars and GDP in current US dollars (i.e., at market exchange rates). World real GDP growth at PPP exchange rates and world real GDP growth at market exchange rates differ markedly at times, since the former gives more weight to emerging economies (Callen 2012). The general recommendation for analyses involving trade (and current account flows in general) is to use the market exchange rates instead of the PPP ones (IMF 2003, box 1.2). The reasons are first, that global trade growth is itself evaluated at market exchange rates, as it is computed using trade in current US dollars as weights, and second, that the advanced economies, which are more trade intensive, are better represented in the world GDP at market exchange rates. In this paper, we follow the literature and use GDP growth at market exchange rates, while providing results based on alternative GDP measures as robustness checks in table S1.2 in the supplementary online appendix. Our robustness checks also include an additional GDP growth indicator that uses trade in current US dollars as weights, which may be even more suitable for trade-related analyses.

10 Estimates of growth in world trade volume vary by data source for a variety of reasons. These include: different cutoff dates and estimates for missing quarterly national accounts data, different aggregation methods, and use of alternative indicators for goods and services trade volumes when national account data is not available.

11 Trade elasticity can be decomposed into a weighted average of the elasticity of different components of trade with respect to income, where the weights are given by the share of the specific category in world trade (see appendix A1).

12 Our analysis with the yearly data, reported below, reveals structural breaks in 1986 and in 2001. Earlier work by Irwin (2002) and Cheung and Guichard (2009) also identifies 1986 as a year of structural break based on Gregory-Hansen tests of cointegration, whereas more recent work by ECB (2016) also identifies 2001 as a structural break. 


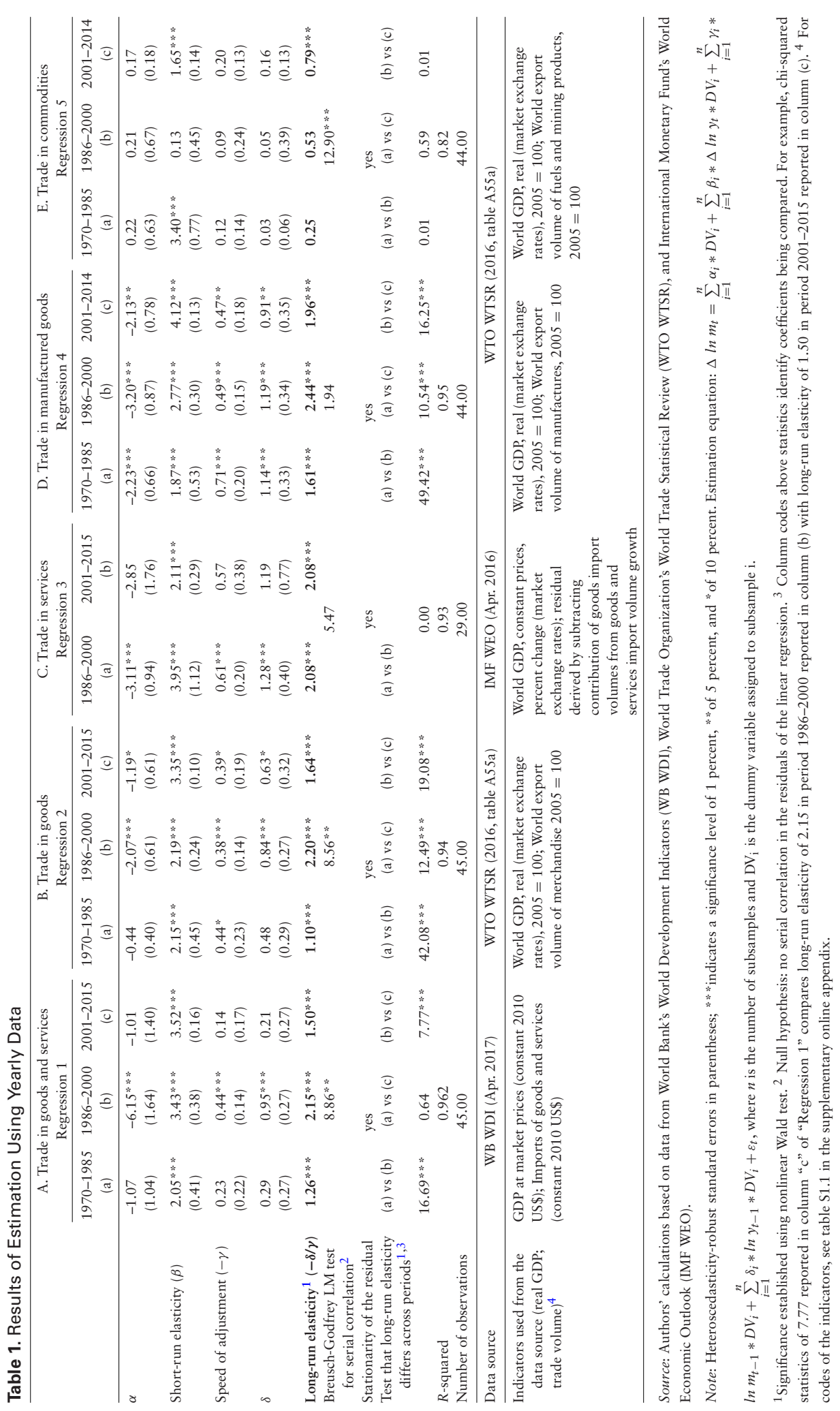


elasticity was 2.2 in the long 1990 s and fell to 1.6 in the 2000s. These two coefficients are statistically different from each other: the chi-squared test statistic of 19.08 is significant at the 1 percent level.

The services trade elasticity and the commodity trade elasticity remained constant or increased in the more recent period relative to the previous period, possibly reflecting the digitization of the economy and the process of rapid and continuing industrialization in emerging economies. The long-run elasticity of world services trade stayed at 2.1 during the 1990 s and 2000s. The elasticity of world commodity trade rose by 0.5 from the 1980 s to the 2000 s, but this difference is not statistically significant. More importantly, the share of services trade in total trade has been remarkably stable at about one-fifth in the past two decades, suggesting that changes in the composition of world trade cannot explain the lower elasticity of trade with respect to GDP in recent years.

The short-run dynamics of the data also present interesting variations during the three periods. The estimates of the short-run elasticity $\beta$ increased over time for total trade, trade in goods, and trade in manufactured goods. These estimates suggest that changes in world income had an increasing short-term impact on world trade. The speed of adjustment $\gamma$ also varied over the three periods but not monotonically, and it is statistically significant across all three periods only for trade in goods and for trade in manufactured goods. ${ }^{13}$

The estimated long-run elasticities vary in magnitude by specification, depending on data source, vintage, or method of aggregation used to compute world real GDP (table S1.2 in the supplementary online appendix). However, the variation in estimates across the alternative specifications is relatively small. More importantly, the dynamic of elasticities over time is robust to changes within each category of trade. Thus, for trade in goods and services together, trade in goods alone, and trade in manufacturing, the 1990s are characterized by a larger long-run elasticity relative to the 1980s and the 2000s. For trade in services and trade in commodities, this is consistently not the case.

While the question of the structural versus the cyclical components of the global trade slowdown will be addressed more precisely below, these regression results already reveal some patterns. Specifically, world trade has become more responsive on impact to changes in world income in the 2000s compared to the long 1990s (higher short-run trade elasticity), but at the same time it has also showed a tendency to grow more slowly than world income (lower long-run trade elasticity). This finding suggests that in addition to cyclical factors, structural elements contributed to the global trade slowdown during 2012-2015. World trade is growing more slowly in recent years, not only because GDP has been sluggish, but also because the long-run relationship between trade and income has changed in recent years. In some sense, the long 1990s appear as an exceptional period, and the reasons for this exceptional behavior of trade will be further investigated in section 5 .

\section{Trade and Income Before and After the Great Recession: Quarterly Data}

In this section, we use (seasonally adjusted) quarterly data to study the changing trade-income relationship within the 2000s. Based on data availability, we divide the period into three portions: the 1990s (19912000), pre-Great Recession (2001q1-2007q4), and post-Great Recession (2008q1-2015q4). The results are presented in table $2 .^{14}$

13 Note that residuals are always found to be stationary. Moreover, the Breusch-Godfrey LM test generally accepts the null hypothesis that there is no serial correlation in the residuals of the linear regression. These results further justify the use of the ECM specification. While we always perform these tests, and report them in key tables, we do not discuss them in the text, as findings are broadly supportive of the model specification used. When serial correlation could not be ruled out based on the LM test, we checked and confirmed that Newey-West standard errors do not change our findings.

14 We do not have quarterly data for 1970-1990. The regression analysis using the first quarterly dataset provides results for the period 1991-2000 that are in line with the findings for the period 1986-2000. The results from the quarterly and the yearly analysis of the 2000s are substantially the same, as expected. Note also that, differently from the yearly estimations, the quarterly ones include dummy variables to control for the global slowdowns in 2001 and 2009. 


\begin{tabular}{|c|c|c|c|c|c|}
\hline & \multicolumn{5}{|c|}{ Trade in goods } \\
\hline & \multicolumn{2}{|c|}{ Regression 1} & \multicolumn{3}{|c|}{ Regression 2} \\
\hline & $\begin{array}{c}1991 \mathrm{q} 1- \\
2000 \mathrm{q} 4 \\
\text { (a) }\end{array}$ & $\begin{array}{c}2001 q 1- \\
2015 q 4 \\
\text { (b) }\end{array}$ & $\begin{array}{c}\text { 1991q1- } \\
2000 \mathrm{q} 4 \\
\text { (a) }\end{array}$ & $\begin{array}{l}2001 q 1- \\
2007 q 4 \\
\text { (b) }\end{array}$ & $\begin{array}{c}2008 q 1- \\
2015 q 4 \\
\text { (c) }\end{array}$ \\
\hline$\alpha$ & $\begin{array}{l}-3.55 * * \\
(0.88)\end{array}$ & $\begin{array}{c}-0.12 \\
(0.26)\end{array}$ & $\begin{array}{l}-3.55 * * \\
(0.91)\end{array}$ & $\begin{array}{l}-4.95 * * \\
(2.24)\end{array}$ & $\begin{array}{c}-0.05 \\
(0.22)\end{array}$ \\
\hline Short-run elasticity $(\beta)$ & $\begin{array}{l}1.71 * \\
(0.92)\end{array}$ & $\begin{array}{l}3.18 * * * \\
(0.37)\end{array}$ & $\begin{array}{l}1.71 * \\
(0.95)\end{array}$ & $\begin{array}{c}2.22 * \\
(1.21)\end{array}$ & $\begin{array}{l}2.63 * * * \\
(0.38)\end{array}$ \\
\hline Speed of adjustment $(-\gamma)$ & $\begin{array}{l}0.43 * * * \\
(0.10)\end{array}$ & $\begin{array}{c}0.06 \\
(0.06)\end{array}$ & $\begin{array}{l}0.43 * * * \\
(0.11)\end{array}$ & $\begin{array}{l}0.72 * * \\
(0.30)\end{array}$ & $\begin{array}{l}0.50 * * * \\
(0.11)\end{array}$ \\
\hline$\delta$ & $\begin{array}{l}1.22 * * * \\
(0.30)\end{array}$ & $\begin{array}{c}0.09 \\
(0.11)\end{array}$ & $\begin{array}{l}1.22 * * * \\
(0.31)\end{array}$ & $\begin{array}{l}1.81 * * \\
(0.79)\end{array}$ & $\begin{array}{l}0.51 * * * \\
(0.14)\end{array}$ \\
\hline Long-run elasticity ${ }^{1}(-\delta / \gamma)$ & $2.85 * *$ & $1.41 * *$ & $2.85 * *$ & $2.51 * * *$ & $1.02 * * *$ \\
\hline Breusch-Godfrey LM test for serial correlation ${ }^{2}$ & \multicolumn{2}{|c|}{1.36} & \multicolumn{3}{|c|}{0.35} \\
\hline Stationarity of the residual & \multicolumn{2}{|c|}{ yes } & \multicolumn{3}{|c|}{ yes } \\
\hline \multirow[t]{2}{*}{ Test that long-run elasticity differs across periods ${ }^{1,3}$} & \multicolumn{2}{|c|}{ (a) vs (b) } & (a) vs (b) & (a) vs (c) & (b) vs (c) \\
\hline & \multicolumn{2}{|c|}{$7.19 * * *$} & $10.19 * * *$ & $292.90 * * *$ & $133.54 * * *$ \\
\hline$R$-squared & \multicolumn{2}{|c|}{0.77} & \multicolumn{3}{|c|}{0.83} \\
\hline Number of observations & \multicolumn{2}{|c|}{99} & \multicolumn{3}{|c|}{99} \\
\hline
\end{tabular}

Data source

IMF WEO (Apr. 2016); IMF IFS

Indicators used from the data source (real GDP; trade volume $)^{4}$

Country-specific quarterly NGDP_RPCH aggregated using (yearly) NGDPD as weights; ratio of TMG_CIF_USD to TMG_D_USD_CIF_IX

Source: Authors' calculations based on data from International Monetary Fund's World Economic Outlook (IMF WEO) and International Monetary Fund's International Financial Statistics (IMF IFS).

Note: Heteroscedasticity-robust standard errors in parentheses; ***indicates a significance level of 1 percent, * of 5 percent, and * of 10 percent. Estimation equation: $\Delta \ln m_{t}=\sum_{i=1}^{n} \alpha_{i} * D V_{i}+\sum_{i=1}^{n} \beta_{i} * \Delta \ln y_{t} * D V_{i}+\sum_{i=1}^{n} \gamma_{i} * \ln m_{t-1} * D V_{i}+\sum_{i=1}^{n} \delta_{i} * \ln y_{t-1} * D V_{i}+\sum_{j=1}^{o} \delta \theta_{j}+\varepsilon_{t}$, where $n$ is the number of subsamples, DV is the dummy variable assigned to subsample $i$, and $\theta_{\mathrm{j}}$ is the dummy variable for each quarter $\mathrm{j}$ from intervals [2001q2, 2001q4] and [2009q 1 to 2009q4].

${ }^{1}$ Significance established using nonlinear Wald test. ${ }^{2}$ Null hypothesis: no serial correlation in the residuals of the linear regression. ${ }^{3}$ Column codes above statistics identify coefficients being compared. For example, chi-squared statistics of 10.19 in column "a" of "Regression 2 " compares the long-run elasticity of 2.85 in period 1991-2000 reported in column (a) with the long-run elasticity of 2.51 in period 2001-2008 reported in column (b). ${ }^{4}$ For indicator names, see table S1.1 in the supplementary online appendix.

Consider first the long-run trade elasticity $(-\delta / \gamma)$. For both the pre- and the post-Great Recession periods, trade is less responsive to changes in income compared to the 1990s, as on average the longrun trade elasticity fell by half, from 2.8 to 1.4 . This finding simply confirms with quarterly data the analysis of the previous subsection. More interestingly, the decline in the long-run responsiveness of trade to income first takes place in the early 2000s, even if it appears to be much stronger in the post-Great Recession world. Specifically, the long-run trade elasticity is 2.5 in the period $(2001 \mathrm{q} 1-2007 \mathrm{q} 4)$ and 1.0 in the second period (2008q1-2015q4). This suggests that the change in the trade-income relationship predated the Great Recession and, hence, cannot be entirely attributed to this event. ${ }^{15}$ These findings are robust to changes in data sources, vintages, and to the use of alternative measures of global real GDP (table S1.3 in the supplementary online appendix). While elasticities from different specifications differ in magnitude from the ones in table 2, they exhibit the same dynamic over time, which serves to strengthen our main conclusion.

The pre- and the post-Great Recession periods display some common features, most notably the lower long-run elasticity compared to the 1990s and the higher short-run responsiveness of trade to income

15 The same pattern, with a larger gap between the 1990s and early 2000s, emerges when allowing the cutoff year to change from 2008 to 2012, in recognition of the fact that 2012 is the first year when the trade slowdown relative to GDP became visible. 
shocks. In this respect, these findings confirm the insights of the previous subsection: The global trade slowdown has deep roots, and the change in the income-trade relationship is not only a byproduct of the financial crisis. But the pre- and post-Great Recession periods also present some remarkable differences. In particular, the long-run link between trade and income appears much more attenuated after the recession. A legitimate question is whether this lower long-run trade elasticity truly reflects a structural shift. Performing a nonlinear Wald test indicates that there is a significant structural break between the period preceding and the one following the recession. However, it is difficult to rule out that the long-run post-crisis trade elasticity is affected by the long cycle that appears to characterize the Great Recession, particularly in the context of advanced economies. ${ }^{16}$

\section{Robustness}

Previous sections have shown that the long-run elasticity of trade volumes to real GDP has declined from the 1990s level and that the decline has its roots before the crisis. Are these findings sensitive to the way subsamples are defined? To examine this issue in more detail, we estimate each year's elasticities using the 10 potential 10-year periods, which include that year. Results are reported in fig. 2 . Note that each year can have between one and 10 elasticity estimates. ${ }^{17}$ The red line represents the median of all elasticities

Figure 2. 10-Year Long-Run Elasticities of Goods and Services Import Volumes to Real GDP

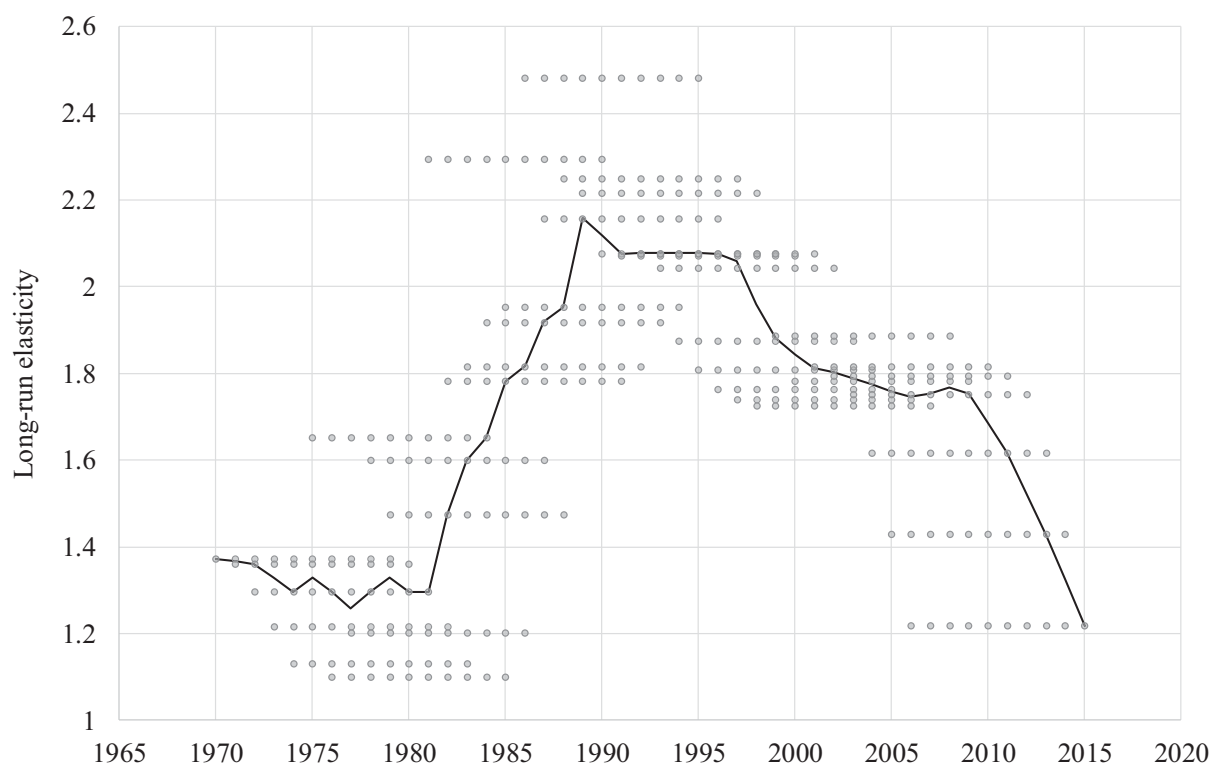

Source: Authors' calculations based on World Bank's World Development Indicators.

Note: Data correspond to "Regression 1" presented in table 1. The indicators used in the estimation are: Imports of goods and services in constant 2010 US\$ and GDP at market prices in constant 2010 US\$ (for indicator codes, see table S1.1 in the supplementary online appendix). Each blue dot represents the long-run elasticity of goods and services import volumes to real GDP derived from a 10-year sample that includes the corresponding year on the $X$-axis. For example, year 1971 is included in two samples: 1970-1979 and 1971-1980. Hence, two blue dots are plotted for that year. The red line connects the median values of the elasticity estimates computed for each year; outlier negative elasticity estimates not shown in the chart and excluded from the calculation of the median.

16 Several factors could in principle disproportionately affect trade. For instance, deleveraging in advanced economies impacts durable goods (that are more trade intensive) to a larger extent than non-durable goods. Confidence about future prospects may have a similar effect on trade, as it also disproportionately affects demand for durables.

17 For example, for 2015, a year at the end of the sample of focus, only one elasticity is computed, which corresponds to the interval 2006-2015. For a year in the middle of the sample, say 1990, 10 elasticities can be computed using all the 10-year periods that include 1990 (from 1981-1990 to 1990-1999). 
corresponding to each year. The chart suggests that there are three levels of roughly stable elasticities: one at around 1.3, during the 1980s, the second at levels above 2, in the 1990s, and the third at around 1.8, in the 2000s. Years since 2012 exhibit a sharp decline in elasticity, to levels experienced in the 1980s. These findings are robust to the use of alternative data sources and vintages, and they apply to trade in goods and services, goods and manufacturing, but not to trade in services and commodities.

\section{Cyclical versus Structural Factors}

The evidence in the previous section creates a presumption that in addition to cyclical factors, there is a structural component to the current slow growth of world trade. Here, we investigate the relative importance of these factors, by decomposing the growth rate of imports into its cyclical and structural components. First, we use the finding of the ECM estimation to identify the long- and short-run components of import growth. Second, within the long-run component, we separate the portion that varies only due to structural factors from the portion that varies only due to cyclical factors. We add the latter to the short-run component derived previously, as that is also associated with cyclical drivers.

We compute the import growth predicted by our model, by applying the estimated coefficients of equation (1) to the actual data. The predicted import growth is given by the following condition:

$$
\widehat{\Delta \ln m_{t}}=\hat{\alpha}+\hat{\beta} \Delta \ln y_{t}+\hat{\gamma} \ln m_{t-1}+\hat{\delta} \ln y_{t-1},
$$

where $\widehat{\Delta \ln m} m_{t}$ is the predicted growth rate of imports at time $\mathrm{t}$ and $\hat{\alpha}, \hat{\beta}, \hat{\gamma}$, and $\hat{\delta}$ are the estimates of coefficients in equation (1).

Note that equation (1) can be rewritten as:

$$
\Delta \ln m_{t}=\alpha_{1}+\beta \Delta \ln y_{t}+\gamma\left[\ln m_{t-1}+\left(\frac{\alpha_{2}}{\gamma}\right)+\left(\frac{\delta}{\gamma}\right) \ln y_{t-1}\right]+\varepsilon_{t},
$$

where $\alpha_{1}+\alpha_{2}=\alpha$. The term in square brackets is the residual of the cointegration equation, which gives the long-run relationship between imports and GDP:

$$
\ln m_{t}=-\left(\frac{\alpha_{2}}{\gamma}\right)-\left(\frac{\delta}{\gamma}\right) \ln y_{t}+u_{t} .
$$

The long-run elasticity is given by $-(\delta / \gamma)$, which we denote as $e^{L R}$, for simplicity. We can use equation (4) to calculate the long-run import growth predicted by the model when periods $t$ and $t-1$ are characterized by the same predicted long-run elasticity $e^{L R}$. Taking the difference of equation (4) evaluated at year $\mathrm{t}$ and equation (4) evaluated at $t-1$, we obtain:

$$
\widehat{\Delta \ln m_{t}^{L} R}=e^{L R} \Delta \ln y_{t} .
$$

Since we already know the estimated long-run elasticity $e^{L R}$, we can use equation (5) to calculate $\Delta \widehat{\ln m_{t}^{L} R}$, that is, the predicted long-run portion of the import growth.

Next, we derive the cyclical part of the import growth predicted by the ECM framework and associated with the short-run cyclical factors (the impact elasticity and the speed of adjustment to the long-run equilibrium of trade). We can obtain it by subtracting $\Delta \widehat{\ln m_{t}^{L} R}$, the predicted long-run growth of imports, from $\widehat{\Delta \ln m}_{t}$, the total predicted import growth:

$$
\widehat{\Delta \ln m_{t}^{S R}}=\widehat{\Delta \ln m_{t}}-\widehat{\Delta \ln m_{t}^{L} R} .
$$

$\Delta \widehat{\ln m_{t}^{L}} R$ can be further decomposed to isolate the cyclical component associated only with fluctuations in output growth around its potential. ${ }^{18}$ This is done by adding and subtracting two terms in equation (5): 
the potential output growth, $\Delta \ln y_{t}^{*}$, and the average of the long-run elasticity across the whole estimation sample, $\overline{e^{L R}}$. After reorganizing terms and adding $\Delta \widehat{\ln m_{t}^{S R}}$, we obtain the following expression for the total predicted import growth rate:

$$
\widehat{\Delta \ln m_{t}}=\underbrace{e^{L R} \Delta \ln y_{t}^{*}}_{\text {STR_PR }}+\underbrace{\Delta \ln m_{t}^{S R}+\overline{e^{L R}}\left(\Delta \ln y_{t}-\Delta \ln y_{t}^{*}\right)}_{\text {CYC_PR }}+\underbrace{\left(e^{L R}-\overline{e^{L R}}\right)\left(\Delta \ln y_{t}-\Delta \ln y_{t}^{*}\right)}_{\text {RES_PR }} .
$$

This provides a decomposition of $\widehat{\Delta \ln m} m_{t}$ into three components. The first one, STR_PR $=e^{L R} \Delta \ln y_{t}^{*}$, represents the purely structural component of the predicted long-run trade growth, and it depends on the long-run elasticity at time $t$ and the yearly growth in potential output, both likely to have only structural underpinnings. The second component, CYC_PR, is the sum of the predicted short-run trade growth $\left(\Delta \widehat{\ln m_{t}^{S} R}\right.$ ) and the portion of the predicted long-run trade growth that is driven by deviations of output growth from potential $\left(\Delta \widehat{\ln m_{t}^{L R} c y c}=\overline{e^{L R}}\left(\Delta \ln y_{t}-\Delta \ln y_{t}^{*}\right)\right)$. The third term, which we label $R E S \_P R$, is a residual and represents a mixture of both cyclical and structural factors that cannot be disentangled.

The impact of a change in the long-run elasticity requires one additional step, namely a comparison of the STR_PR portion of trade growth in two years belonging to periods characterized by different steady state elasticities, for example the long 1990s and the 2000s.

Figure 3 reports the decomposition of the growth of world imports of goods for the period 1970-2015 into its structural and cyclical components, using the estimation results presented in "Regression 2" of

Figure 3. Decomposition of Growth of Goods Trade Volume (percentage points)

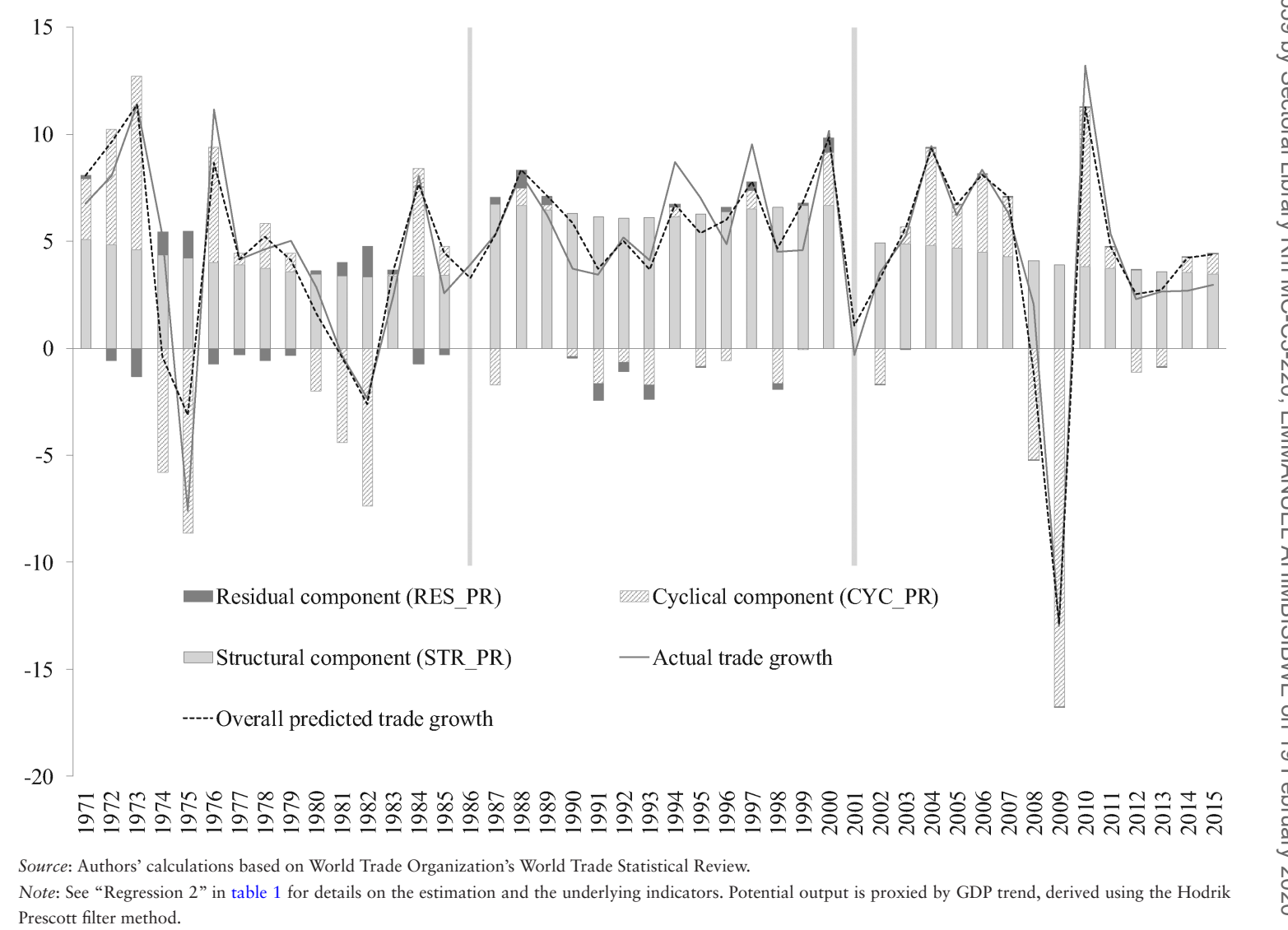


table 1. That estimation does not factor in the structural break that happened around the time of the Great Recession. The blue bars capture the structural component of the long-term import growth predicted by the model (STR_PR), the orange bars represent the predicted cyclical component of import growth (CYC_PR), and the purple bars indicate the residual RES_PR. In addition, the figure reports the predicted ECM import growth and the actual growth of world imports.

Figure 3 provides some useful insights. First, a comparison between actual import growth and ECM import growth shows that the model performs reasonably well in predicting trade growth over the past 45 years. The mismatch after 2011 is due to assuming a constant long-run elasticity throughout the 2000s. Second, the structural long-run portion of import growth tends to explain a significant portion of the total growth for most of the sample. Third, the portion capturing cyclical effects dominates during periods of crisis and post-crisis recovery, such as the trade collapse in 2008 and 2009 and the trade rebound in 2010. The dominance of cyclical effects reflects both large deviations of income growth from potential in those years and the effect of the short-run trade elasticity, which is generally larger than the long-run trade elasticity and has been increasing over time. Yet trade tends to quickly adjust to its long-run equilibrium as the impact of income shocks is offset.

Does the current global trade slowdown reflect cyclical or structural factors? Both are clearly involved. The structural portion of import growth has been strongly subdued in the 2000s relative to the long 1990s (4 percent on average during 2001-2015 versus 6.5 percent on average during 1986-2000). In the postcrisis period, the cyclical component of world import growth has been weak, reflecting primarily the closing of the output gap.

A focus on the period 2012-2015 may help provide some insights on the relative importance of cyclical and structural factors in the current trade slowdown but also underscore the need for an accurate account of all the structural breaks affecting the estimation sample (table 3). During 2012-2015, the average import growth was 3.9 percentage points lower than the average growth during 2002-2007 (line 1d,

Table 3. Contributions to Growth of Goods Trade Volume (percent)

Actual trade growth Structural component Cyclical component Residual component Unexplained

1. Yearly dataset; change in 2000

a $1995-2000$

b $2002-2007$

2012-2015

d 2012-2015 vs 2002-2007

2012-2015 vs 1995-2000

2. Yearly dataset: change in 2008

a 1995-2000

b 2002-2007

2012-2015

d 2012-2015 vs 2002-2007

e 2012-2015 vs 1995-2000

3. Quarterly dataset; changes in 2000 and 2007

a $1995-2000$

b 2002-2007

2012-2015

d 2012-2015 vs 2002-2007

e 2012-2015 vs 1995-2000
(1)

(2)

6.8
6.5
2.6
-3.9
-4.1

6.8

6.5

2.6

$-3.9$

$-4.1$

8.4

7.6

1.9

$-5.7$

$-6.6$

5.9

2.4

$-3.3$

7.7

6.1

1.9

$-4.2$
(3)

$\begin{array}{rr}6.5 & 0.0 \\ 4.7 & 2.0 \\ 3.6 & -0.1 \\ -1.1 & -2.1 \\ -3.0 & -0.1\end{array}$

5.7

$-3.5$

$-5.8$

0.8

0.4

1.4

0.2

$-1.2$

$-0.3$
(4)

(5)

$\begin{array}{rr}0.2 & 0.0 \\ 0.0 & -0.2 \\ 0.0 & -0.8 \\ 0.0 & -0.7 \\ -0.2 & -0.9\end{array}$

0.1

0.2

$-0.1$

$-0.3$

$-0.2$
0.0

$-0.2$

$-0.8$

$-0.9$

1.3

$-0.4$

0.0

0.4

$-1.2$

0.1

$-0.1$

0.0

0.1

$-0.1$

Source: Authors' calculations based on data from World Trade Organization's World Trade Statistical Review and International Monetary Fund's World Economic Outlook and International Financial Statistics.

Note: See "Regression 2" in tables 1 and 2, and also table S1.4 in the supplementary online appendix for details on the underlying indicators. Potential output is proxied by GDP trend, derived using the Hodrik Prescott filter method. Any discrepancies between sums of constituent figures and totals are due to rounding. 
column 1, of table 3). According to the model, around 29 percent of this decline is imputed to a lower structural portion of long-run growth while 71 percent is the result of cyclical factors. ${ }^{19}$ Since the model assumes a constant long-run elasticity in the 2000s, the structural effect of 29 percent should be seen as a lower bound, as it reflects variation in the growth of potential output only.

Factoring in the downward shift in the long-run elasticity following the crisis (implied by the quarterly ECM model) suggests that structural factors account for more than 29 percent in the decline of trade growth from the pre-crisis period of the 2000s to the post-crisis years. We illustrate this finding using the results of two alternative specifications (spec. 2 and 3 in table 3). The first specification is similar to the one discussed above, except for the fact that the long-run elasticity is allowed to change in 2008 instead of 2000 (see table S1.4 in the supplementary online appendix for estimation results). By extending the high long-run elasticity of the 1990s until the crisis time, this approach yields an upper bound for the structural contribution to the trade slowdown from 2002-2007 to 2012-2015. The second specification is the quarterly estimation reported in table 2, which allows the long-run elasticity to change in both 2000 and 2007. ${ }^{20}$ These two specifications suggest that the structural contributions to the decline in goods import growth in the period 2012-2015 relative to 2002-2007 amount to 84 and 73 percent, respectively. ${ }^{21}$

\section{Factors Explaining the Decline in Trade Elasticity}

The previous sections have established that the trade-income relationship has changed over time and that the lower long-term trade elasticity helps explain the global trade slowdown in recent years. We also examined whether shifts in world trade composition, particularly the relative importance of goods and services, could be related to the observed decline in the long-run trade elasticity. We found that this decline is due to the fall of the goods trade elasticity, particularly manufacturing trade, in the 2000s.

In this section, we take a closer look at the causes of the decline in the long-run goods trade elasticity of income. We investigate three possible explanations: (i) changes in the structure of trade, particularly those associated with the international fragmentation of production; (ii) changes in the composition of GDP, particularly the share of investment in aggregate demand; and (iii) changes in the trade regime, particularly the pace of trade opening and the possible rise in protectionism. Before testing the relative importance of these factors directly, we provide some circumstantial evidence on how far each might have contributed to the observed trade slowdown.

Needless to say, the explanations discussed in this paper are neither mutually exclusive nor exhaustive. They are not mutually exclusive, as changes in vertical specialization, for example, are in part associated with changes in trade policy, as a more open trade regime is a contributing factor to production fragmentation. These explanations are not exhaustive because the diminished responsiveness of trade may be related to other factors. For instance, rising wages in certain developing countries or the shale gas revolution in the United States may also have had an influence on the trade-income relationship. However, the explanations listed above are the ones that are commonly discussed in the literature (see, in particular, Irwin [2002]) and are the logical starting point of any analysis of the structural causes of the global trade slowdown.

19 Calculations are based on lines $1 \mathrm{~b}, 1 \mathrm{c}$, and $1 \mathrm{~d}$ of table 3 . For example, the contribution of structural factors of $29 \%=$ $(-1.1 \%) * 100 /(-3.9 \%)$, where $-1.1 \%=3.6 \%-4.7 \%$.

20 In table 3, the actual trade growth corresponding to the quarterly dataset differs from the one in the yearly dataset because the former is based on data from the IMF International Financial Statistics while the latter is based on data from the World Bank World Development Indicators.

21 The roles of the structural and cyclical components are different when we compare the pre-crisis period of the 2000s with the averages for the long 1990s or the post-crisis years with the long 1990s. In the latter case, for instance, structural factors explain up to 90 percent of the trade slowdown (rows 1e, 2e, and 3e of table 3). Details are reported in table 3. 


\section{Changes in Vertical Specialization}

One explanation for the changing long-run trade elasticity is the varying pace of international vertical specialization (fig. 4). The information and communication technology shock of the 1990s led to a rapid expansion of global supply chains, with an increasing number of parts and components being imported, especially by emerging economies for processing and re-export (Baldwin 2011). The resulting increases in back-and-forth trade in components led to measured trade racing ahead of national income. The transition to a world where production is increasingly internationally fragmented in the long 1990s is compatible with the higher long-run trade elasticity for that period (Escaith, Lindenberg, and Miroudot 2010). Conversely, the decline in the long-term responsiveness of trade with respect to income in the 2000s may well be a symptom that the technology shock of the 1990s has been absorbed and that the process of international production fragmentation has slowed down. ${ }^{22}$

Figure 4. Measures of World Vertical Specialization $(2000=100)$, 1995-2014

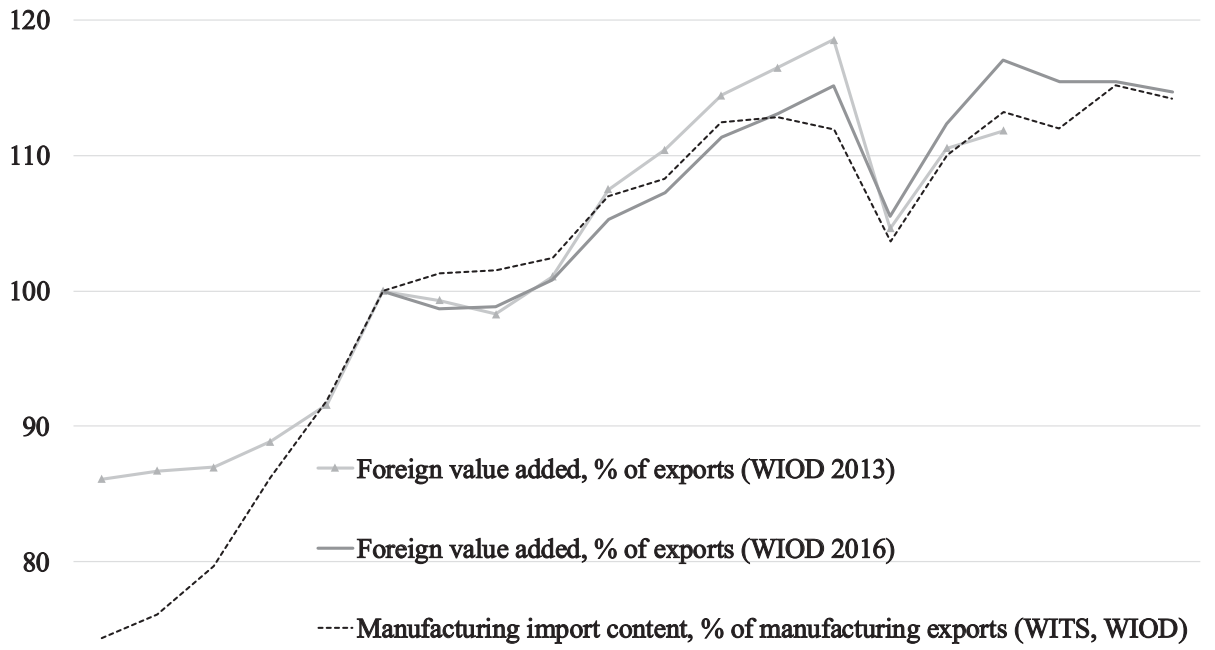

70

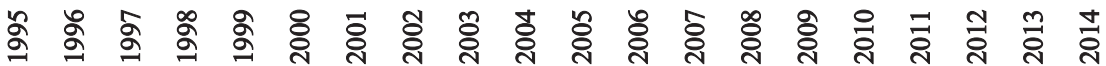

Source: Authors' calculations based on World Integrated Trade Solution (WITS) and World Input-Output Database (WIOD).

Note: The measures of vertical specialization based on WIOD 2013 and 2016 data are shares of foreign value added in gross exports of goods and services. The third measure is based on data on manufacturing trade from the WITS and on sectoral output from WIOD.

The changing long-term relationship between manufacturing trade and income that was documented in the previous subsection may be a symptom of changing international production relations. ${ }^{23}$ In this respect, China and the United States are paradigmatic of two different situations. Because of data limita-

22 While the focus here is on the long-run trade elasticity, one should also expect a discrepancy between the short- and long-run dynamics of trade and income data. The persistently high short-run elasticity for the 2000s documented in section 3 may reflect the fact that the impact of a GDP shock is larger in a world where global supply chains are more developed. The literature on the trade collapse discussed several mechanisms through which vertical specialization may increase the short-term responsiveness of trade to GDP, for example, if expenditure declines more in vertically specialized sectors (Bems, Johnson, and Yi 2011), if there are inventory-also called bullwhip_effects (Altomonte et al. 2012), or if there is re-nationalization of production chains (Buono and Vergara-Caffarelli 2013).

23 Similarly, we find evidence that the elasticity of durables trade has decreased from 2.7 in the long 1990 s to 0.8 in the 2000s. This is consistent with the changing structure of global supply chains, which are more concentrated in complex goods such as durables relative to non-durable sectors (Ferrantino and Taglioni 2014). For brevity, these regression results are not reported. 
tions, we can only present some circumstantial evidence. The manufacturing supply chain between China and the United States to a large extent took the form of parts and components being imported by the former and then being assembled into final goods that were exported to the latter. The diminishing importance of such trade is reflected most clearly in the falling share of imports of parts and components in China's manufacturing exports, from the peak in the mid-1990s of 34 percent to the current share of approximately 22 percent (fig. 5a). ${ }^{24}$ Measures of participation in global value chains (GVCs) can also be

Figure 5. China's Participation in Global Value Chains (GVCs)

a. Ratios of imported intermediate goods to gross exports (percent)

- Ratio of intermediate imports to exports of goods*

--- Ratio of imports of parts and components to exports of manufacturing (RHS)**

55

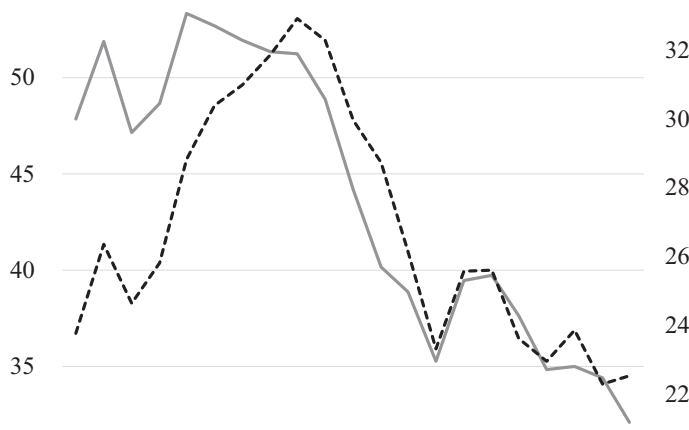

30

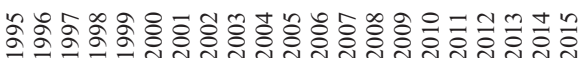

28

26

20 b. GVC participation measures, as a share of gross exports (percent)

--- Total GVC participation

- Backward GVC participation

- Forward GVC participation

2

30

Source: Authors' calculations based on World Integrated Trade Solutions (WITS) and World Input-Output Database.

Note: "Intermediates defined as categories 22, 42, and 53 in UN Comtrade's BEC Classification. "*Parts and components defined as categories 42 and 53 in UN Comtrade's BEC Classification plus 651 through 657 in SITC Revision 3. Manufacturing defined as SITC3 categories 5 through 8 minus 68 and 891 . In panel b: Backward GVC participation captures the foreign value-added embodied in gross exports. Forward GVC participation captures the domestic value-added embodied in other countries' exports. Total GVC participation is the sum of the backward and forward GVC participation. GVC participation is computed by splicing the data from the 2013 and 2016 versions of WIOD.

computed from the World Input-Output Database (WIOD) (fig. 5b). ${ }^{25}$ Backward GVC participation is defined as the foreign value-added embodied in exports. This measure is similar in spirit to the measure depicted in fig. 5a, and behaves similarly. Forward GVC participation is defined as the domestic value-added embodied in the exports of other countries. This measure shows a gradual rise over the whole period. Total GVC participation, the sum of the two measures, behaves similarly to backward GVC participation,

24 The World Trade Organization (2014a, 2004b) also investigates the evolution of China's position in global value chains. They find that foreign inputs contained in China's exports increased by 13.8 percent between 2000 and 2009 ("Evolution of GVC participation and its components, selected Asian economies," in WTO [2014b]) and that between 1995 and 2008, China's position became more downstream (figure C.7 in WTO [2014a]). The apparent difference from our conclusions arises first of all because the WTO figures include imports not just of parts and components but also of fuel and raw materials. Since the prices of commodity inputs increased significantly in the 2000s, lumping together components and raw materials may create the impression that China's exports became more import dependent even though it was reducing its reliance on imported parts and components. Despite this difference, the data on which the WTO charts are based, and to which we were given access, show that in fact China became more upstream since 2005 and that foreign inputs contained in exports actually declined by 3 percent after 2005 .

25 The backward and forward GVC participation measures (referred to as VS and VS1, respectively, in Hummels, Ishii, and Yi 2001) are computed using the methodology described in Koopman, Wang, and Wei (2014). 
peaking in the early 2000s and then declining. The fall in these measures reflects the substitution of domestic inputs for foreign inputs by Chinese firms, a finding that is corroborated by evidence of increasing domestic value-added in Chinese firms (Kee and Tang 2016). ${ }^{26}$

The reduced responsiveness of manufacturing trade with respect to income for the United States mirrors in some ways developments in China. In the 1990s, as US firms increasingly relocated production stages outside national borders, trade tended to respond more to changes in income as variations in domestic demand were increasingly met by imports. In recent years, the international fragmentation process seems to have leveled off. In fact, US manufacturing imports as a share of GDP have been stable at around 8 percent since the turn of the century, after nearly doubling in the preceding decade and a half. Interestingly, Chinese manufacturing imports as a share of GDP rose from 10 percent at the beginning of the long 1990s to almost 30 percent in the early 2000s and have sharply declined since then.

\section{Changes in the Composition of Aggregate Demand}

Another plausible explanation for the lower long-run trade elasticity concerns the changing composition of GDP. Different components of aggregate demand have different trade intensities, investment having a larger import content than private consumption and, especially, government spending. For this reason, the changing composition of GDP in the aftermath of the crisis, with its sharp decline in investment and surge in government spending, has been shown to play an important role in explaining the relationship between trade and macroeconomic dynamics during the trade collapse (Bussiere et al. 2013).

It is possible that a prolonged reduction in the components of GDP that have the highest import content may also lead to a decline in the long-run trade elasticity. The composition of world GDP has changed throughout the 2000s (fig. S1.2 in the supplementary online appendix). The share of investment in world aggregate demand grew fast in the period before the Great Recession and then declined. Can this change in the composition of aggregate demand explain the decline in the long-run trade elasticity?

Weak investment may help explain the low trade elasticity for the post-Great Recession period that we documented in section $2 .{ }^{27}$ However, the changing composition of demand cannot on its own explain the decline in the long-run world trade elasticities throughout the 2000s. If this channel were driving the changing long-run relationship between trade flows and GDP, the world trade elasticity in the pre-Great Recession period should have been increasing, as the share of investment in aggregate demand was rising, the share of public consumption was falling, and private consumption remained stable. As discussed in section 3 , this is not what we find in the data.

\section{Changes in Trade Policy}

Finally, a change in protection seems to be a natural candidate for the lower responsiveness of world trade to income, as an increase in trade barriers in the 2000s could have contributed to lower growth of world trade (and particularly so in the aftermath of the financial crisis). However, the recorded increase in protectionist measures since the outset of the crisis has not been substantial, although persistently increasing. The WTO trade restrictiveness indicators—capturing border measures such as tariff increases,

26 These changes do not mean that China is turning its back on globalization. As discussed in Kee and Tang (2016), the enhanced availability of inputs domestically is in part linked to growing foreign direct investment in these industries. Moreover, there may be a geographical dimension to these changes, with China's coastal regions beginning to source relatively more from the Chinese interior, because transport and communication costs have declined more sharply with the interior than with the rest of the world. Trade integration may now be taking the form of greater internal trade than international trade, which is captured by official statistics.

27 Boz, Bussiere, and Marsilli (2015) provide evidence consistent with this hypothesis. They use the model estimates of Bussiere et al. (2013) that are based on an "import-intensity adjusted" demand, which gives higher weight to components of demand with higher import content such as investment. They show that the model predictions are close to actual trade growth for a set of advanced economies during the global trade slowdown. 
trade remedies, and new customs controls-show a modest increase in the share of world trade covered by new import restricting measures since the crisis. Since October 2008, this share computed for all WTO member and observer countries varied between 0.9 and 1.4 percent (WTO 2014c). World Bank data on Temporary Trade Barriers (Temporary Trade Barriers Database 2016), which focuses on trade remedies such as antidumping and countervailing duties, provide a similar picture.

Given the relatively small share of trade that has been affected, protectionist trade policies are unlikely to have played a significant role in explaining the reduction in the world trade elasticity and, hence, in the current trade slowdown. However, a word of caution may be warranted. First, changes in still-opaque non-tariff measures are not captured by standard measures of protection, and they may be playing a role that our analysis cannot account for. ${ }^{28}$ Second, it is still well possible that the slower pace of trade liberalization in the 2000s relative to the long 1990s, rather than a surge in protection, may contribute to explain the declining responsiveness of world trade to GDP.

Indeed, part of the explanation for the slowdown in global trade may be that the benefits of past reforms have matured and new reforms have languished. In the 1990s and early 2000s, reforms in anticipation of and resulting from WTO membership allowed countries, most notably China, to rapidly integrate into the global trading system even as supply chains were built in Asia, Europe, and North America. Applied tariffs fell from averages of nearly 30 percent to less than 10 in emerging and developing countries and from 6 to 2 percent in industrial countries (fig. S1.3 in the supplementary online appendix). The liberalization led to a significant increase in the ratio of imports to GDP in all countries, with the ratio for emerging and developing countries higher by 4 percent, on average, through most of the 1990s and early 2000s. The process of unilateral liberalization slowed down after this period, and multilateral negotiations have stalled. While some major regional trade initiatives are today in the pipeline, few have so far had the transformative effect of, say, the North American Free Trade Agreement in 1994 or the reforms in Eastern European countries in preparation for their accession to the European Union.

\section{Relative Importance of Explanatory Factors}

In this section, we examine econometrically the influence on real import growth of the key factor we have identified, vertical specialization, while controlling for the role of the trade policy regime and the share of investment in demand. Since there are too few observations to conduct a meaningful world-level analysis, we work with data at the country-year and country-sector-year levels. The focus on trade in goods reflects the finding of the previous sections that changes in global trade elasticity are due primarily to changes in trade in goods.

The indicator used to measure vertical specialization captures both backward and forward GVC participation, described at the beginning of section 4. We first computed the indicator for the period 1995-2014 by splicing the data from the 2013 and 2016 versions of WIOD. The country-specific trade policy regime is assessed using import-weighted averages of product-specific tariffs. We recognize that non-tariff barriers could also play a role, but they are difficult to measure and data on these barriers are generally not available over time. ${ }^{29}$ To capture changes in the composition of global demand, we rely on the share of investment in GDP provided by the World Bank's World Development Indicators.

The specification takes the following form when applied to yearly country-level panel data for the period 1995-2014:

$$
\Delta \ln M_{c t}=\alpha_{1}+\beta_{1 a} V S_{c t}+\beta_{2 a} I N V_{c t}+\beta_{3 a} T A R_{c t}+\gamma_{1} \Delta \ln G D P_{c t}+\delta_{1} \Delta \ln R E E R_{c t}+F E_{c}+F E_{t}+\varepsilon_{t},
$$

28 The Global Trade Alert initiative considers a broader range of policy instruments relative to the WTO and has documented a larger number of protectionist measures since the crisis (Evenett 2014). This count, however, includes both trade-restrictive and trade-promoting measures, particularly export subsidies and various forms of fiscal incentives to exporting firms, with potentially contrasting effects on the volume of trade.

29 See Bown and Crowley (2016), Goldberg and Pavcnik (2016), and Ederington and Ruta (2016). 
where the dependent variable is the growth rate of goods import volumes of country $c$ in year $t$, and $V S_{c t}$, $I N V_{c t}$, and $T A R_{c t}$ denote growth rates in vertical specialization, the share of investment in GDP, and the tariff measure, respectively. ${ }^{30}$ The specification also includes country and year fixed effects and controls for domestic import demand, proxied by the growth of country-specific gross domestic product $\left(\Delta \ln G D P_{c t}\right)$, and for relative prices, proxied by the country-specific real effective exchange rate $\left(\triangle \ln R E E R_{c t}\right)$.

Next, we estimate a specification using panel data at the country-sector level (focusing on manufacturing sectors only and covering the period 1995-2009 due to data constraints), which includes countrysector and year fixed effects. Three of the regressors are country-year specific: GDP $\left(\Delta \ln G D P_{c t}\right)$, the control for relative prices $\left(\Delta \ln R E E R_{c t}\right)$, and the share of investment in GDP $\left(\Delta \ln I N V_{c t}\right)$.

$$
\Delta \ln M_{c s t}=\alpha_{2}+\beta_{1 b} V S_{c s t}+\beta_{2 b} I N V_{c t}+\beta_{3 b} T A R_{c s t}+\gamma_{2} \Delta \ln G D P_{c t}+\delta_{2} \Delta \ln R E E R_{c t}+F E_{c s}+F E_{t}+\varepsilon_{t} .
$$

Estimation results are provided in table 4. Columns (1) and (2) are based on specification (8), while columns (3) and (4) correspond to specification (9). In columns (2) and (4), regressions are weighted by trade flows-since changes in larger countries and sectors will have a larger effect on global trade than changes in smaller countries and sectors. Errors are clustered at the country level since three of the regressors vary only at this level. The coefficients of vertical specialization and share of investment in GDP are significant in all specifications, while those of tariffs are not significant in any specification.

The lower panel of table 4 reports for each specification, the contribution of those factors (out of the three analyzed here) that are found to be significant. The contribution is computed as the difference in the average growth of a particular factor in the 2000s and the 1990s, multiplied by the estimated coefficient. The contribution is reported as a share of the difference in the average growth of the dependent variable in the 2000s and the 1990s. Vertical specialization emerges as the most important factor in both specifications. It accounts for between one-quarter and one-half of the decline in import growth from the 1990 s to the 2000s in all specifications. ${ }^{31}$ The share of investment in GDP accounts for about one-tenth of the decline import growth.

\section{Conclusion}

To assess whether the global trade slowdown of recent years is cyclical or structural, we analyze the relationship between trade and income in the past four decades. We demonstrate the rise of the longrun world trade elasticity in the long 1990s and its decline in the 2000s, which set in before the Great Recession. This inverted-U pattern of the world trade elasticity is driven by goods trade, particularly manufacturing, not by commodities or services trade. We use the estimates of an error correction model to decompose import growth and show that structural factors play a large role in explaining the recent low rates of world trade growth.

We then study the determinants of the trade slowdown in the 2000s. We investigate three candidates: changes in vertical specialization, changes in the composition of GDP, and changes in trade policy. We find evidence that the changes in trade growth are significantly related to changes in the pace of expansion of global supply chains. The high trade elasticity of the long 1990s reflected increasing production fragmentation, an engine that appears to have exhausted its propulsive energy in the 2000s. The share of

30 We use the growth rate of goods import volumes as the dependent variable rather than the income elasticity of imports to be consistent with the literature in this area (e.g., IMF 2016). Regressions using the income elasticity of imports (computed as the ratio of the yearly growth rate of imports to the yearly growth rate of GDP) as a dependent variable do not change the results in this section.

31 IMF (2016) finds a significant, but smaller, contribution of changes in vertical specialization to the trade slowdown, using data from EORA MRIO. Data from WIOD, which are the basis of our analysis, cover a smaller country sample relative to EORA, but they measure cross-border value-added trade flows more precisely. These measures are needed to compute the indices of GVC participation at the country and country-sector level that are used in the regressions. 
Table 4. Effect of Vertical Specialization on the Growth of Goods Import Volume

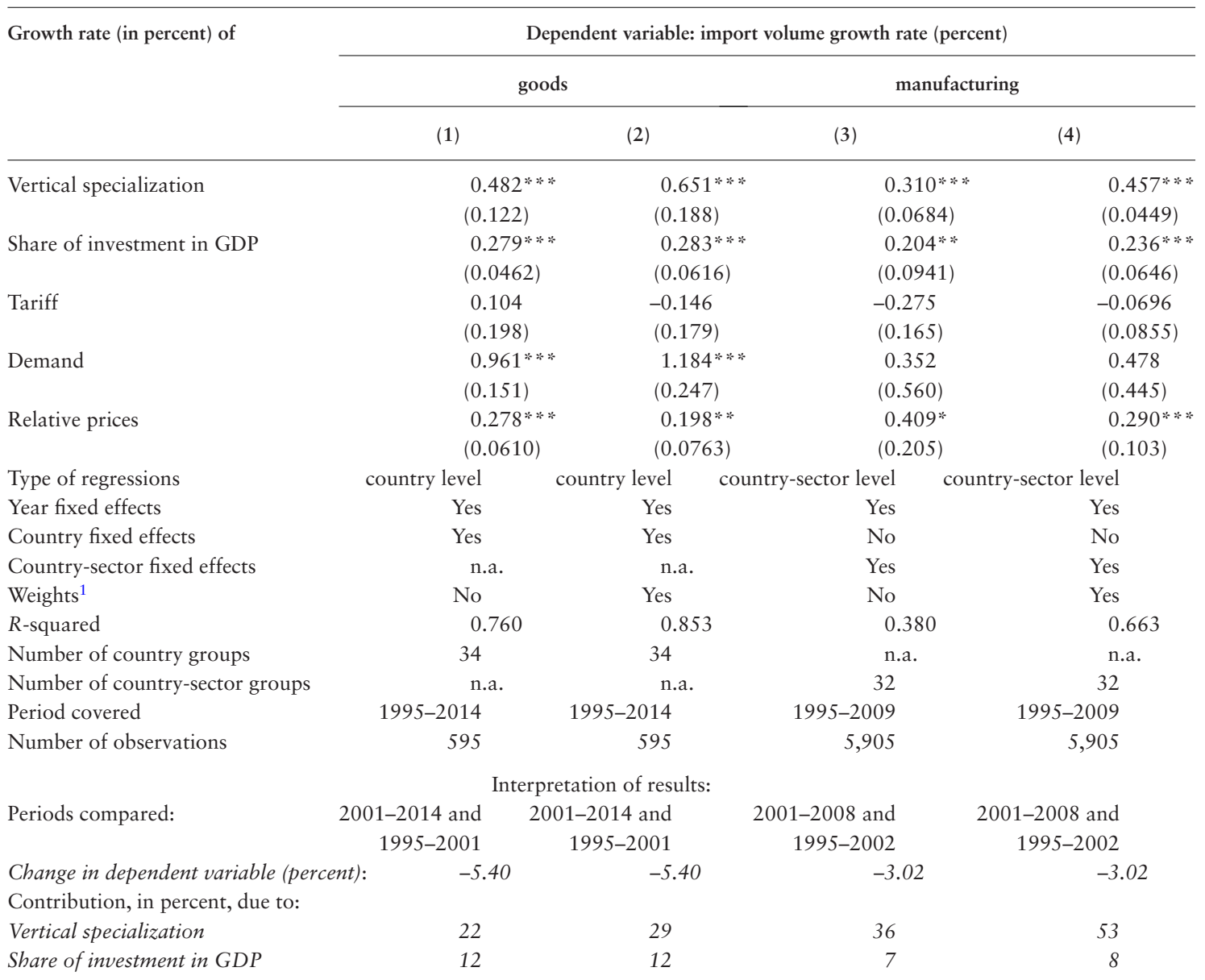

Source: Authors' calculations based on data from the World Trade Organization's Merchandise Trade Indices Annual Dataset, April 2017 (for country import volumes), World Input-Output Database (for country-sector real imports and vertical specialization measures), World Bank's World Development Indicators, April 2017 (for real GDP data by country and for shares of investment in GDP), International Monetary Fund's International Financial Statistics (for real effective exchange rates), and World Integrated Trade Solution (for tariffs).

Note: Growth rates are defined as $100 * \log$ difference. Vertical specialization is the sum of backward linkages (foreign value-added embodied in exports) and forward linkages (domestic value-added embodied in the exports of other countries) as a share of gross exports. Vertical specialization indicators computed using World InputOutput Database 2013 and World Input-Output Database 2016 have been spliced to obtain a series that covers more years. Results are robust to using data from either one of the two versions of the World Input-Output Database. The vertical specialization indicators are deflated in (3) and (4) and normalized by gross exports in (1) and (2). Heteroscedasticity-robust standard errors corrected for clustering at country level are reported in parantheses: $p<0.10, * *<0.05$, *** $p<0.01$.

${ }^{1}$ In specification (2), weights are country-specific import values in current US\$ from the WB WDI. In specification (4), weights are country-sector specific import values, in current US\$ from World Input-Output Database.

investment in GDP has declined after the financial crisis and can help explain the lower trade elasticity since then, but was increasing in the pre-crisis period and, therefore, cannot explain the decline in the early 2000s. We do not find evidence that changes in the trade regime (measured as changes in average tariffs) are a significant determinant of the lower trade elasticity in the 2000s, although we cannot exclude the possibility that murky forms of protectionism are contributing to poorer trade performance following the crisis.

The changing long-term relationship between trade and income that underpins the trade slowdown is, in part, a symptom of changing international production relations. To the extent that a finer international 
division of labor is isomorphic to factor-augmenting technical change (Grossman and Rossi-Hansberg 2008), a slower pace of its expansion could mean that world trade is contributing less to global growth in the 2000s, particularly after the crisis, than it did in the long 1990s. This issue merits further investigation.

Looking ahead, there is still considerable scope to enhance the international division of labor by drawing in regions that have been at the margin of global supply chains, such as South Asia, Africa, and South America. How and when these untapped opportunities will be seized depends on the steps these regions take to liberalize trade in goods and services, particularly transport and communications that facilitate the geographical fragmentation of production.

\section{Appendix A1: Decomposition of the World Trade Elasticity}

Define the long-run world income elasticity of trade, $\sigma_{W}$, as the percentage change in total world imports (or exports) in volume terms $\left(m_{W}\right)$ over the percentage change in real world income $\left(y_{W}\right)$, where $m_{W}$ and $y_{W}$ can be interpreted as the equilibrium levels of imports and income, respectively. ${ }^{32}$ That is,

$$
\sigma_{W}=\frac{\Delta m_{w} / m_{w}}{\Delta y_{w} / y_{w}}
$$

We first show that the world trade elasticity can be decomposed as a weighted average of the elasticities of different trade categories (e.g., goods and services). To keep things simple, define $z=z_{1}+z_{2}$ and $\Delta z=$ $\Delta z_{1}+\Delta z_{2}$, where $z=m_{\mathrm{w}}, y_{\mathrm{w}}$ and 1 and 2 are the two trade categories (the extension to $n$ trade categories is straightforward and is omitted).

We can write

$$
\sigma_{W}=\frac{\left(\Delta m_{1}+\Delta m_{2}\right) /\left(m_{1}+m_{2}\right)}{\Delta y_{W} / y_{W}}=\frac{\frac{\Delta m_{1}}{m_{1}} \frac{m_{1}}{m_{W}}+\frac{\Delta m_{2}}{m_{2}} \frac{m_{2}}{m_{W}}}{\Delta y_{W} / y_{W}}=\sigma_{W}^{1} \frac{m_{1}}{m_{W}}+\sigma_{W}^{2} \frac{m_{2}}{m_{W}},
$$

where $\sigma_{W}^{j}$ is the elasticity of goods/services imports to global income and $m_{j} / m_{W}$ (with $j=1,2$ ) is the share of goods/services imports in world imports.

This decomposition indicates that the world trade elasticity can decline for two reasons. First, for given trade weights, the elasticity is lower if the responsiveness to GDP of goods trade and/or services trade decline. Second, for given goods and services trade elasticities, the world trade responsiveness to GDP is lower if the share of world imports of the trade category with lower elasticity increases over time.

We next obtain the world trade elasticity as a weighted average of the elasticity of regions' (or, equivalently, countries') imports to their own income. Again, for simplicity, we focus on two regions, denominated as region 1 and 2 .

$$
\sigma_{W}=\frac{\frac{\Delta m_{1}}{m_{1}} \frac{m_{1}}{m_{W}}+\frac{\Delta m_{2}}{m_{2}} \frac{m_{2}}{m_{W}}}{\frac{\Delta y_{1}}{y_{1}} \frac{y_{1}}{y_{W}}+\frac{\Delta y_{2}}{y_{2}} \frac{y_{2}}{y_{W}}}=\frac{\frac{\Delta m_{1}}{m_{1}} \frac{m_{1}}{m_{W}}}{\frac{\Delta y_{1}}{y_{1}} \frac{y_{1}}{y_{W}}} \frac{\frac{\Delta y_{1}}{y_{1}} \frac{y_{1}}{y_{W}}}{\frac{\Delta y_{W}}{y_{W}}}+\frac{\frac{\Delta m_{2}}{m_{2}} \frac{m_{2}}{m_{W}}}{\frac{\Delta y_{2}}{y_{2}} \frac{y_{2}}{y_{W}}} \frac{\frac{\Delta y_{2}}{y_{2}} \frac{y_{2}}{y_{W}}}{\frac{\Delta y_{W}}{y_{W}}}=\sigma^{1} \frac{m_{1}}{m_{W}} \frac{\frac{\Delta y_{1}}{y_{1}}}{\frac{\Delta y_{w}}{y_{W}}}+\sigma^{2} \frac{m_{2}}{m_{W}} \frac{\frac{\Delta y_{2}}{y_{2}}}{\frac{\Delta y_{W}}{y_{W}}},
$$

where $\sigma^{i}$ is the elasticity of region $i$ 's imports to its own income. This elasticity is weighted by region $i$ 's share in world imports and by the elasticity of region $i$ 's income to world income (i.e., the growth rate of region $i$ relative to world growth).

This decomposition indicates that a decline of the world trade elasticity can be explained by three factors. A first element can be a decline in the elasticity of a region's imports to its own income. A second factor can be the increasing import share of a region with lower trade elasticity. Finally, a third element is the increasing relative growth of a region with lower trade elasticity. 


\section{References}

Abiad, A., P. Mishra, and P. Topalova. 2014. "How Does Trade Evolve in the Aftermath of Financial Crises?" IMF Economic Review 62 (2): 213-47.

Altomonte, C., F. Di Mauro, G. Ottaviano, A. Rungi, and V. Vicard. 2012. "Global Value Chains During the Great Trade Collapse: A Bullwhip Effect?” Working Paper No. 1412, European Central Bank, Frankfurt am Main, Germany.

Baldwin, R., ed. 2009. The Great Trade Collapse: Causes, Consequences and Prospects. London: CEPR.

Baldwin, R. 2011. “Trade and Industrialisation After Globalisation's 2nd Unbundling: How Building and Joining a Supply Chain Are Different and Why It Matters.” NBER Working Paper No. 17716, National Bureau of Economic Research, Cambridge, MA.

Bems, R., R. C. Johnson, and K.-M. Yi. 2010. "Demand Spillovers and the Collapse of Trade in the Global Recession." IMF Economic Review 58 (2): 295-326.

- 2011. "Vertical Linkages and the Collapse of Global Trade." American Economic Review Papers and Proceedings 101 (3): 308-12.

- 2013. "The Great Trade Collapse.” Annual Review of Economics 5 (1): 375-400.

Bown, C. P., and M. A. Crowley. 2016. “The Empirical Landscape of Trade Policy.” In The Handbook of Commercial Policy, vol. 1A, edited by K. Bagwell and W. Staiger, 3-108. Amsterdam, Netherlands: Elsevier.

Boz, E., M. Bussiere, and C. Marsilli. 2015. “Recent Slowdown in Global Trade: Cyclical or Structural.” In Global Trade Slowdown: A New Normal, edited by B. Hoekman, 55-70. London: CEPR.

Buono, I., and F. Vergara-Caffarelli. 2013. “Trade Elasticity and Vertical Specialization.” Working Paper No. 924, Bank of Italy.

Bussiere, M., G. Callegeri, F. Ghironi, G. Sestieri, and N. Yamano. 2013. "Estimating Trade Elasticities: Demand Composition and the Trade Collapse of 2008-2009." American Economic Journal: Macroeconomics 5 (3): 11851.

Callen, T. 2012. "Purchasing Power Parity: Weights Matter." Finance \& Development.

Cheung, C., and S. Guichard. 2009. "Understanding the Word Trade Collapse.” Working Paper No. 729, OECD Economics Department, Paris.

Constantinescu, C., A. Mattoo, and M. Ruta. 2016. “Does the Global Trade Slowdown Matter?” Journal of Policy Modeling 38 (4): 711-22.

Davies, G. 2013. "Why World Trade Growth Has Lost Its Mojo." Financial Times Blog, September 29. https://www.ft.com/content/9ad0678e-8c39-3eb8-8f5f-787e9a93f0f6.

Donnan, S. 2014. “OECD Warns on Global Trade Slowdown.” Financial Times, May 27. https://www.ft.com/content/ 0ec846d8-e5b7-11e3-aeef-00144feabdc0.

European Central Bank (ECB). 2016. "Understanding the Weakness in Global Trade. What Is the New Normal?" ECB Occasional Paper Series 178, European Central Bank, Frankfurt.

Ederington, J., and M. Ruta. 2016. "Non-Tariff Measures and the World Trading System.” In The Handbook of Commercial Policy, vol. 1B, edited by K. Bagwell and R. W. Staiger, 211-77. Amsterdam: Elsevier.

Escaith, H., N. Lindenberg, and S. Miroudot. 2010. "International Supply Chains and Trade Elasticity in Times of Global Crisis.” WTO Staff Working Paper ERSD-2010-08, World Trade Organization, Geneva, Switzerland.

Evenett, S. J. 2014. The Global Trade Disorder: The $16^{\text {th }}$ Global Trade Alert Report. London: CEPR.

Ferrantino, M., and D. Taglioni. 2014. “Global Value Chains in the Current Trade Slowdown.” Economic Premise No. 137, World Bank, Washington, DC.

Freund, C. 2009. “The Trade Response to Global Downturns: Historical Evidence.” Policy Research Working Paper No. 5015, World Bank, Washington, DC.

—. 2016. “The Global Trade Slowdown and Secular Stagnation.” Peterson Institute of International Economics, April 20. https://piie.com/blogs/trade-investment-policy-watch/global-trade-slowdown-and-secular-stagnation.

Goldberg, P. K., and N. Pavcnik. 2016. “The Effects of Trade Policy.” In The Handbook of Commercial Policy, vol. 1A, edited by K. Bagwell and R. W. Staiger, 161-206. Amsterdam: Elsevier.

Grossman, G. M., and E. Rossi-Hansberg. 2008. “Trading Tasks: A Simple Theory of Offshoring.” American Economic Review 98 (5): 1978-97. 
Haugh, D., A. Kopoin, E. Rusticelli, D. Turner, and R. Dutu. 2016. “Cardiac Arrest or Dizzy Spell: Why Is World Trade So Weak and What Can Policy Do About It?” OECD Economic Policy Paper No. 18, Organization of Economic Cooperation and Development, Paris.

Hummels, D., J. Ishii, and K.-M. Yi. 2001. “The Nature and Growth of Vertical Specialization in World Trade.” Journal of International Economics 54(1): 75-96.

International Monetary Fund (IMF). 2003. World Economic Outlook: Public Debt in Emerging Markets. Washington, DC: IMF.

- 2011. When and How to Adjust Beyond the Business Cycle? A Guide to Structural Fiscal Balances. Washington, DC: IMF.

- 2016. “Global Trade: What's behind the Slowdown?” In World Economic Outlook: Subdued Demand: Symptoms and Remedies, 63-119. Washington, DC: IMF.

Irwin, D. 2002. "Long-Run Trends in World Trade and Income.” World Trade Review 1 (1): 89-100.

Kee, H. L., and H. Tang. 2016. “Domestic Value Added in Exports: Theory and Firm Evidence from China.” American Economic Review 106 (6): 1402-36.

Koopman, R., Z. Wang, and S.-J. Wei. 2014. “Tracing Value-Added and Double Counting in Gross Exports.” American Economic Review 104 (2): 459-99.

Krugman, P. 2013. "Should Slowing Trade Growth Worry Us?" New York Times Blog, September 30. https://krugman.blogs.nytimes.com/2013/09/30/should-slowing-trade-growth-worry-us/.

_. 2014. "Flattening Flattens.” New York Times Blog, November 3. https://krugman.blogs.nytimes.com/2014/11/ 03/flattening-flattens/.

Levchenko, A., L. Lewis, and L. Tesar. 2010. "The Collapse of International Trade during the 2008-09 Crisis: In Search of the Smoking Gun.” IMF Economic Review 58 (2): 214-53.

Ollivaud, P., and C. Schwellnus. 2015. "Does the Post-Crisis Weakness of Global Trade Solely Reflect Weak Demand?” OECD Journal: Economic Studies 2015 (1): 269-97.

Rajan, R. 2014. "Make in India, Largely for India.” Talk delivered at the Bharat Ram Memorial Lecture, December 12, New Delhi, India.

Temporary Trade Barriers Database (TTBD) (accessed June 26, 2014), http://econ.worldbank.org/ttbd/.

Timmer, M. P., B. Los, R. Stehrer, and G. J. de Vries. 2016. "Research Memorandum Number 162: An Anatomy of the Global Trade Slowdown Based on the WIOD 2016 Release," Groningen Growth and Development Centre, Groningen, the Netherlands.

World Trade Organization (WTO). 2014a. Trade and Development: Recent Trends and the Role of the WTO. Geneva: WTO.

- 2014b. International Trade Statistics 2014. Geneva, WTO.

. 2014c. Overview of Developments in the International Trading Environment: Geneva, Annual Report by the Director-General. 